\title{
Refractory T Lymphoblastic Leukemia/Lymphoma
}

National Cancer Institute

\section{Source}

National Cancer Institute. Refractory T Lymphoblastic Leukemia/Lymphoma. NCI

Thesaurus. Code C8696.

T-lymphoblastic leukemia/lymphoma resistant to treatment 